DOI: https://doi.org/10.46991/AFA/2021.17.2.141

\title{
R. LEMKIN'S CONTRIBUTION TO THE DEVELOPMENT \\ OF MODERN INTERNATIONAL LAW AND \\ INTERNATIONAL CRIMINAL LAW
}

\author{
Ewa Sałkiewicz-Munnerlyn* \\ Calisia Academy in Kalisz
}

\begin{abstract}
This article presents the significance and impact of Lemkin's concept of genocide on the development of international law. We will randomly present the jurisprudence of international courts such as the ICJ, the ICC, the ICTY and the ICTR, which analyzed the concepts of genocide, including cultural heritage crimes. Residual functions of the ICTY, including oversight of sentences and consideration of any appeal proceedings initiated since 1 July 2013, are under the jurisdiction of a successor body, the International Residual Mechanism for Criminal Tribunals (IRMCT). The article also invites attention to the impact on $\mathrm{R} 2 \mathrm{P}$ and the human rights, as well as international state responsibility and the individual responsibility.
\end{abstract}

Keywords: cultural genocide, ICC, ICTY, ICTR, ICJ, R2P, Katyn massacre.

\section{Introduction}

The article deals with Raphael Lemkin's contribution to the development of modern international law and international criminal law. The principal aim of this research consists in showing why the lacking part of the Genocide Convention, i.e. the cultural genocide is important nowadays. We explain the reasons why this part was omitted during the preparatory work for the drafting of the text of the Convention on the prevention of genocide.

We present the application of the Genocide Convention in proceedings before the International Criminal Court (ICC), the International Criminal Tribunal for Rwanda (ICTR) and the International Criminal Tribunal for

\footnotetext{
* ewasalkiewiczmunnerlyn@gmail.com
}

This work is licensed under a Creative Commons Attribution-NonCommercial 4.0 International License.
Received: 19.08 .2021

Revised: 13.09 .2021

Accepted: 01.10 .2021

(C) The Author(s) 2021 
Yugoslavia (ICTY) as well as the Application of the Genocide Convention in a procedure before the International Court of Justice (ICJ) in The Hague.

I have applied the method of observation, including textual observations of Lemkin's texts where he speaks about the importance of the concept of cultural genocide to be included in the

Convention on the prevention of Genocide which unfortunately didn't happen. I also implement the method of analysis in the study of different cases of cultural genocide. The method of deduction helps me reveal how important it is for the International Criminal Court to prevent further cases of cultural genocide through strict decisions.

\section{Preparatory work for the drafting of the text of the Convention on the prevention of genocide}

Raphael Lemkin first used the new term "genocide" in 1943, and introduced his concept in his 1944 book "Axis Governments in Occupied Europe". The UN General Assembly unanimously adopted Resolution 96/I on Genocide Crime in Lake Success, NY, 11.12.1946, proposed by R. Lemkin.

The first sentence of the resolution, written by Lemkin, says:

Genocide is a denial of the right to exist for entire human groups, just as murder is a denial of the right to life of an individual human being. Such a denial of the right to exist shakes the conscience of man, causes a great loss to humanity in matters of cultural and other contributions represented by these human groups, and is also contrary to moral law and to the spirit and purposes of the United Nations. (Lemkin, 1946, pp. 188-189)

This resolution became a fundamental starting point for the two-year travaux préparatoires, which eventually led to the adoption of the "revolutionary" Convention on the Prevention and Punishment of the Crime of Genocide of December 9, 1948. All the time, Lemkin lobbied for the adoption of the Convention. To this end, before its adoption, in Paris he met with the Papal Nuncio, Cardinal Angelo Roncalli, later Pope John XXIII. He noted:

The human life and religion are sacred things that cannot be the subject of political haggling.... I enclose the report of the Special Committee on the Crime of Genocide. Unfortunately, 
Article 3, which represents the soul (l'âme) of the entire convention, was rejected at first reading. Let us hope that through your initiative it will be restored and even changed so that the United Nations can declare that man lives not only with bread, but also in need of spiritual nourishing (Raphael Lemkin Collection, Box 6, folder 2, p.154).

Cardinal Roncalli writes in his Memoirs: "On October 27, 1948 in the afternoon, I spoke for an hour with Prof. R. Lemkin, who informed me about the Genocide and it interested me very much." (Roncalli, 2006, p. 563).

Unfortunately, we do not know whether there has been any initiative on the part of the Nuncio to restore Article 3 to the Convention.

\section{The issue of cultural genocide}

Documents from the preparatory work for the Convention testify to Lemkin's long struggle in upholding the concept of cultural genocide, and Lemkin himself wrote in the Memorandum of the Convention: "Cultural Genocide is the most important part of the Convention.” (Korey, 2001, pp. 41-43). In his words:

World culture is only as strong and vital as the spiritual forces which are brought to it by various contributing peoples. If these peoples are annihilated, their cultural heritage is also destroyed. The destruction of a people by genocide results in an immediate, irretrievable loss to world culture'. (Lemkin, 1946, p. 364)

As Balakian rightly points out (Balakian, 2013, pp. 59-70), in 1948 Lemkin continued to conceptualize his notion of genocide as encompassing three primary domains: physical existence, biological continuity (through procreation) and spiritual or cultural expression. Lemkin himself said about the cultural genocide:

Cultural genocide can be accomplished predominately in the religious and cultural fields by destroying institutions and objects through which the spiritual life of a human group finds its expression, such as houses of worship, objects of religious cult, schools, treasures of art and culture. By 
destroying spiritual leadership and institutions, forces of spiritual cohesion within a group are removed and the group starts to disintegrate. This is especially significant for the existence of religious groups. Religion can be destroyed within a group even if the members continue to subsist physically. (Raphael Lemkin Collection, Box 6, folder 2, p154)

As is well known, there were two versions of the draft Convention, the first of May 1947 prepared by the Secretariat and the second version of April 1948 ad hoc Committee of the ECOSOC draft (Morsink, 1999, p. 1021; Schreiber, 2013, pp. 252-275). The concept of cultural genocide was covered in the first version in Article I, 3, and in the second version in Article III. In the final version, adopted on December 9, 1948, the definition of genocide was severely stripped down and cultural genocide disappeared from the draft Convention. Why did this happen? The United States and France were opposed from the outset, while only Poland, the Soviet Union, Venezuela, Siam, China and Lebanon supported it, suggesting that this issue be discussed in the debate on human rights and the protection of minorities. Another proposal was that instead of the Convention, cultural genocide should be included in the text of the Universal Declaration of Human Rights, which was to be adopted a day later, on December 10, 1948, but that didn't happen either.

As already mentioned, Lemkin was very keen on Article 3 (cultural genocide) to be included in the Convention, as he also wrote to Cardinal Roncalli in Paris on October 30, 1948:

Cultural genocide is based on acts of violence directed against persons of religion or culture, such as clergy and intellectuals, and against objects of worship, religious buildings and cultural objects. This concept can be formulated legally with almost the same accuracy as it was for the enemies of religion and culture. However, the line of defense in this case is less strong and favorable than the attack line. I am sure, Your Excellency, that you will be able to strengthen the spirit of state leaders who in most cases have good will but who are awaiting an initiative and spiritual direction. (Lemkin, Op.cit. Box 6, folder 5, p. 154) (Transl.: Ewa Sałkiewicz-Munnerlyn) 
The Convention on the Prevention and Punishment of the Crime of Genocide was adopted unanimously on December 9, 1948, without abstentions, by the $3^{\text {rd }}$ UN General Assembly at its session in Paris, the day before the universal declaration of the adoption of human rights occurred (GłogowskaBalczerzak, 2013, pp. 79-97; Gasparyan et al, 2016; Luck, 2018, pp.1-38).

The issue of cultural genocide was referred to again in 1984, when the possibility to amend the Convention was discussed in the Subcommittee on the Prevention of Discrimination and the Protection of Minorities. The UN Special Rapporteur B. Whitaker proposed the adoption of an optional protocol to address cultural genocide, but this proposal was not accepted.

As is well known, the Universal Declaration of Human Rights does not regulate the cultural dimension of genocide, but contains only a general right to free participation in the cultural life of a society. It was only adopted in 1966 when a provision (Article 27) concerning the cultural rights of ethnic, religious and linguistic minorities was introduced in the International Covenant on Civil and Political Rights.

Unfortunately, the concept of cultural genocide does not function in instruments of international law, either binding (e.g. agreements) or soft law (e.g. declaration). There are voices in the doctrine about the need to create a document that obliges states to criminalise cultural genocide. This document would be part of the international criminal law, with all the consequences, while the guarantees on national minorities contained in the human rights instruments created other protection mechanisms (Nersessian, 2005, pp.7-8) ${ }^{1}$.

It should be noted that recently national courts have been dealing with the issue of cultural genocide, even though, as highlighted above, there is no legal regulation in the Convention on the Prevention of the Crime of Genocide. In a 2015 report, the Truth and Reconciliation Commission in Canada found that the policy adopted from 1883 to 1998 against the children of indigenous Canadian (Aboriginal) people was a cultural genocide (Honouring the Truth, 2015). The Guatemalan court, judging Jose Rios Montt for his genocidal actions, also emphasized the importance of cultural genocide (The Trial of Efrain Rios Montt, 2018). Hallmarks of cultural genocide are borne in the systematic annihilation of the Mayan Ixil ethnic group and the destruction of their culture, particularly when women, and especially those who were pregnant, were deprived of their lives as well as the possibility of passing on knowledge of culture and history to their future generations. 
The International Criminal Court which deals with cases of individuals accused of genocide, not States, in 2010 issued an arrest warrant against the Sudanese President Omar Al-Bashir, accused of committing a crime of genocide (Second decision, 2019).

Although the concept of cultural genocide was rejected in the course of the work on the Convention, international tribunals in the process of applying and interpreting the existing definition of genocide highlighted the important role of cultural considerations. Thus, for example, the International Criminal Tribunal for Rwanda (ICTR) ${ }^{2}$ held that the intention constituting a subjective element of genocide (mens rea) could be revealed by a certain pattern of action taken by the perpetrators (Wierczyńska, 2015; Heidrich, 2013, pp. 159-182; Szpak, 2012). Such a pattern is the repeated actions aimed at destroying the cultural heritage of particular ethnic, religious, national or racial groups, which may indicate a particular intention and constitute an integral part of the fact that these acts constitute genocide.

Similarly, in the case KRSTIC ${ }^{3}$ the International Criminal Tribunal for former Yugoslavia (ICTY) took as evidence the specific intention of the individual responsible for the crimes of genocide, attacks on cultural and religious objects and symbols, and in this particular case considered as evidence of the intention to destroy the group, the deliberate destruction of mosques and houses belonging to its members. In the same case, the ICTY noted, however, that despite the development of customary law, the definition of genocide remains invariably limited to activities aimed at the physical or biological destruction of a protected group (Wierczyńska, 2006-2008, pp. 83-93; Wierczyńska \& Jakubowski, 2016, pp. 39-60).

Thus, it becomes obvious that the concept of cultural genocide still remaining unregulated by the Convention, leaves room for the further realization of genocidal intentions and the perpetration of other genocidal crimes against humanity.

\section{Application of the Convention in a procedure before the International Court of Justice (ICJ) in the Hague}

The International Court of Justice, in its judgment from February 26, 2007 in the Application of the Convention and Punishment of the crime of genocide (Bosnia and Herzegovina v. Serbia and Montenegro) (Case concerning application of, 2007, p. 43), Destruction of historical, religious and cultural 
property (paragraphs 335-344), quoted the view of the ICTY concerning the actions of the perpetrators and determined that some of the crimes committed during the war in Yugoslavia were something more than crimes against humanity or war crimes.

With regard to the prevention of genocide in the context of responsibility for protection, it is necessary to recall the order of the International Court of Justice in the case of Bosnia and Herzegovina v. Serbia, in which the Court ordered Serbia to "take all measures within its means to prevent the commission of the crime of genocide" (Order on interim measures, 1993 p. 52; Sałkiewicz-Munnerlyn, 2009).

In one of its reports, the International Campaign for Tibet in the context of China's cultural genocide in Tibet, stressed that actions known as cultural genocide could be the first step to committing the most serious crimes, citing the Doctrine of Responsibility for Protection (R2P). One has to agree with Schabas' view, that the principle of responsibility for protection is an excellent complement to the obligation to prevent the crime of genocide contained in Article I of the Convention (Schabas, 2006).

It should be stressed out that the definition of genocide has not changed to this day. Both Article 4 of the ICTY, Article 2 of the ICTR and Article 6 of the ICC have adopted the definition of genocide from the Convention on the Prevention and Punishment of the Crime of Genocide. This means that the statutory definition does not refer to cultural groups as protected groups and cultural genocide is not sanctioned by the statutes of those Tribunals. This definition is widely recognised by the international community and is a rule of customary law. This was underlined by the ICJ in Case concerning armed activities in the territory of the Congo (Case concerning armed activities, 2006, pp. 1-54), Jurisdiction of the Court and admissibility of the application, Judgment of 3 February, 2006, paragraphs 58 and 60, ruling that the prohibition of genocide is the norm of jus cogens and that the provisions contained in the Convention impose erga omnes obligations on States (Application of the Convention, 2007, p. 6).

International law prohibits the deliberate destruction and looting of cultural goods during armed conflicts. This prohibition is based on Treaty Law and International Customary Law (ICL) rules. Since the end of World War II, such acts committed by individuals during armed conflicts (both international and non-international) can be considered war crimes or crimes against humanity that correspond to international criminal responsibility. In particular, this is 
apparent from the 1954 Hague Convention on the protection of cultural goods in the event of armed conflict (Article 28) and additional protocols to the Geneva Conventions of August 12, 1949, concerning the protection of victims of armed conflict and protocol II to the 1954 Hague Convention adopted in 1999, also applicable to non-international armed conflicts (Article 24) ${ }^{4}$.

A vivid example of cultural genocide is the genocide of the Armenian culture - the culture of the oldest Christian country in the world where Christianity spread as early as AD 40. The genocidal actions were committed by Turquie in the form of the destruction of religious shrines in Ani, the mediaeval Armenian capital, particularly in the $11^{\text {th }}$-century church of Ani, as well as in the monastery complexes of Van - region of Aghbak, St. Bartholomew the Apostle Monastery - an Armenian monastery built in the $13^{\text {th }}$ century $\mathrm{AD}$ and today located near the town of Başkale in Van Province, Turkey. One can state with no doubt that the destruction of all those monuments was a terrible and irreparable damage caused to the valuable world heritage of mankind. Moreover, during the Armenian genocide in 1915-1917, more than 2,300 Christian monuments, including the early $4-5^{\text {th }}$ centuries, were looted, burned and destroyed by the Turks.

Recently there has been cultural genocide in Nagorno-Karabakh, during the conflict between Armenia and Azerbaijan. As a result of the 44-day war, launched by Azerbaijan with the direct involvement of Turkey and foreign terrorist fighters against Artsakh (Nagorno-Karabakh) on September 27, 2020, the Armenian cultural and religious heritage appeared to be under an imminent threat of destruction and/or appropriation. As it was shown in a position paper on crimes against cultural property, submitted by the delegation of the Republic of Armenia at the $14^{\text {th }}$ United Nations Congress on Crime Prevention in 2021, throughout the war, the Armenian cultural and religious monuments, including the Holy Saviour Ghazanchetsots Cathedral of Shushi, Artsakh, and Hellenistic and Armenian archaeological site of Tigranakert, an ancient city founded by Armenian king Tigranes the Great in 95-55 BC, were deliberately targeted and partially destroyed. These attacks are a blatant violation of the 1954 Hague Convention and its Protocols and the International Humanitarian Law. But this was not anything new for the Azerbaijani side for the most notorious act of cultural genocide conducted by Azerbaijan has been the destruction of several thousand engraved cross-stones (khachkars) and tombstones of the medieval Armenian cemetery of Old Jougha (Julfa) in Nakhijevan during 1997-2006 (Maghakian \& Pickman, 2019). In fact, this was the largest number of 
khachkars formerly located at the Armenian cemetery in Jougha which contained approximately 10,000 khachkars in 1648, whereas in 1998 only 2,700 khachkars remained. Between 1998 and 2006, Azerbaijan destroyed the entire medieval Necropolis. It is not by chance that the expert group of the Switzerland-Armenia Association (SAA) defined the crime committed in Jougha as ethnocide (Accountability for destruction, 2012; Sawa, 2019).

Another obvious fact of destruction can be mentioned in connection with the Turkish invasion of Cyprus in 1975, where more than 500 churches and monasteries were looted and destroyed: more than 15,000 icons of saints, innumerable sacred liturgical vessels, gospels and other objects of great value have literally vanished. A few churches have been turned into mosques, museums, places of entertainment or even hotels, like the church of Ayia Anastasia in Lapithos. At least three monasteries have been turned into barracks for the Turkish army (Ayios Chrysostomos in the Pentadactylos Mountains, Acheropoiitos in Karavas and Ayios Panteleimonas in Myrtou).

Many genocide trials have not been concluded with a final judgment, such as the Katyn massacre, before the European Court of Human Rights (Case of Janowiec, 2013).

Concepts such as R2P (Responsibility to Protect) were created as a continuation of protection against the crime of genocide, in the event of mass violations of human rights (Kułaga, 2014, pp. 102-124). The importance of the responsibility to protect in the context of the crime of genocide is confirmed by the fact that the issue in the UN system has been placed in the competence of the UN Secretary-General's Special Adviser on the crime of genocide. The Commission on Intervention and Sovereignty of States, the author of the concept, stated in its report that R2P has multiple international legal sources (The Responsibility to Protect, 2001, pp.47-57). They can be found in the norms of sovereignty, in the Charter of the United Nations, and in international treaties on humanitarian law and human rights. The latter group includes the Convention for the Prevention and Punishment of the Crime of Genocide of 1948, the Geneva Conventions of 1949, together with the two Additional Protocols of 1977, the Covenant on Civil and Political Rights and the 1966 Covenant on Economic, Social and Cultural Rights, the Statute of the International Criminal Court. This understanding of R2P is equally confirmed by the Special Adviser to the Secretary-General for genocide, pointing to Article 1 of the Convention on the Prevention and Punishment of the Crime of Genocide as a source of state responsibility for the protection of its own 
people ${ }^{4}$. Similarly, the United Nations Secretary-General confirms in a 2009 report that R2P is the result of the existing international law (Report of the Secretary-General, 2009) ${ }^{5}$.

\section{Conclusion}

The influence made by Raphael Lemkin on the development of modern international law and international criminal law is enormous. Although Article III (cultural genocide) was not included in the Convention, the interest in this issue did not disappear. It led in the 1970s and 1980s to a new discussion and to the establishment by the United Nations in 1982, of the Working Group on Indigenous Populations as a subsidiary organ of the Sub-Commission on the Promotion and Protection of Human Rights (Study of the problem, 1982).

It should be emphasized that the return of cultural genocide to the international debate took place in the framework of human rights, not the Genocide Convention, as demanded in 1948. In 1993, the Working Group produced the Draft Declaration on the Rights of Indigenous Peoples (E/CN.4/Sub.2/1993/26).

According to Article 7, "indigenous peoples have the collective and individual right not to be subjected to ethnocide and cultural genocide". It then called for the "prevention of and redress for" a number of acts, beginning with "any action which has the aim or effect of depriving them of their integrity as distinct peoples, or of their cultural values or ethnic identities" (UNCHROR, $45^{\text {th }}$ Sess., Annex 1)

The Draft Declaration was debated and amended several times and finally the reference to cultural genocide was deleted. The General Assembly adopted the Declaration in 2007 by a vote of 143 to 4 (with 11 abstentions). The four against were the same countries that had opposed Article III almost sixty years earlier (Australia, Canada, New Zealand, and the United States) (The United Nations Declaration, 2007) $)^{5}$ Later, these countries decided to support the Declaration (DESA- Department of Economic and Social Affairs Indigenous Peoples) which does not refer explicitly to cultural genocide, but refers to the protection of the world's cultural heritage. According to Article 7(2) of the Declaration, "indigenous peoples have the collective right to live in freedom, peace and security as distinct peoples and shall not be subjected to any act of genocide or any other act of violence, including forcibly removing children of the group to another group" (The United Nations Declaration, 2007). This 
aspect of cultural genocide was retained in the Genocide Convention. In the past, in countries like Australia and Canada, the indigenous children had been removed from their families and communities for reeducation and cultural assimilation, and it had resulted in charges of cultural genocide (Akhavan, 2016; Moses, 2010; Morsink, 1999, pp. 1009-1060; Mako, 2012, pp. 175-94; Francioni, 2004, pp. 1209-1228; Short, 2010, pp. 831-846).

We can also find examples that some of the armed groups destroying the world cultural heritage have been engaged in the abduction of children in an attempt to separate them from cultural and religious ties.

The Convention does not set out the nature and extent of the prevention obligation. Article IV of the Convention says: "Persons committing genocide or any of the other acts enumerated in Article III shall be punished, whether they are constitutionally responsible rulers, public officials or private individuals". It is up to states to establish domestic law that would allow them to be found guilty of genocide, regardless of whether they are constitutionally responsible members of the government, public officials, or private individuals (BenNaftali, 2009, pp. 36-44).

After the massacres in the Balkans, Somalia, or Rwanda and Srebrenica in 1995 (Bieńczyk-Missala, 2019), the UN Secretary-General Kofi Annan argued, that the twenty-first century must be the century of prevention (Annan, 1998), and proclaimed the need to adopt a "culture of prevention" and to look through a "prevention lens" when undertaking development activities (Prevention of armed conflict, 2001).

The legacy of R. Lemkin can also be seen in the concept of the responsibility to protect (R2P), presented in the report of the International Commission on Intervention and State Sovereignty of 2001 (The Responsibility to Protect, 2001). The issue of state sovereignty and the obligation to prevent the situations of mass suffering has been given a new approach. This idea of the International Community concerning the responsibility of states for protection of civilians, has been adopted by the UN General Assembly in the Final Document, during the United Nations World Summit in 2005. The preventive support to states for civil protection has been announced and the necessity to develop early-warning capabilities and UN prevention instruments has been recognized. It is worth recalling, that these provisions have been adopted by consensus by all member countries of the UN (The 2005 World Summit Outcome, 2005).

During the International Conference of the Great Lakes Region in 2006, 
the Protocol on the Prevention and Punishment of the Crime of Genocide, War Crimes and Crimes Against Humanity and All Forms of Discrimination were adopted (Bieńczyk-Missala, 2018, pp. 70-78). Also, the International Court of Justice, in the case - Application of the Convention on the Prevention and Punishment of the Crime of Genocide (Bosnia and Herzegovina v. Serbia and Montenegro), indicated the interim measures of protection for Bosnia and Herzegovina against former Yugoslavia (now Serbia) (Sałkiewicz-Munnerlyn, E, 2009). Later, in the same case in 2007, the ICJ confirmed the obligation of the FRY to prevent the genocide in Srebrenica in June 1995 and ruled that FRY had not complied with its obligation to prevent genocide and had not imposed a penalty on perpetrators as provided for in Article I of the Convention. The ICJ noted that the prevention obligation applies to all parties. It is not territorially limited, and refers to an immediate and effective action using all necessary funds (Application of the Convention, 2007, p. 43).

R. Lemkin's works also influenced the concept of state sovereignty and its limitation in case of a humanitarian intervention, especially for humanitarian reasons. It was one of the most controversial issues, since the interventions in Somalia in 1993, Kosovo in 1999, and Libya in 2011. He believed that in case of genocide, the crime of crimes, the international community must provide assistance to victims. It needs to intervene, if the state itself, cannot or does not want to help and intervene. We can say, he was in favour of humanitarian intervention to protect lives (Jacobs, 2010, p. 153-164).

\section{Notes}

1. David Nersessian in his "Rethinking Cultural Genocide Under International Law, Human Rights Dialogue: Cultural Rights" mentions that it is necessary to refer to the issue of cultural genocide once again: "It is hardly a satisfactory situation and it is time to revisit the issue put aside by the Convention's drafters through a new treaty dealing specifically with cultural genocide. These efforts should be preceded by a comprehensive analysis of state practice and the opinion juris to ascertain the current status of cultural genocide under customary international law. The need is patent. Cultural genocide is a unique wrong that should be recognized independently, and that rises to the level of meriting individual criminal responsibility. After all, if indeed the highest values of a society are expressed through its criminal laws, what message is being conveyed by not labeling acts of cultural genocide as 
criminal? Perhaps a message better left unsent" (Cf. "Cultural Rights", Spring 2005, Series 2, No 12, p. 7-8).

2. In the International Criminal Tribunal for Rwanda (ICTR) the prosecutors were Climent Kayishema and Obed Ruzindana. Cf. Case No ICTR-95-1-T, par. 89.

Retrieved 04.05.2021 from https:/unictr.irmct.org/sites/unictr.org/files/case-documents/ ictr-95-1/appeals-chamber-judgements/en/010601.pdf

3. The Prosecutor at the International Criminal Tribunal for former Yugoslavia (ICTY) was Radislav Krstic. Cf. Case No IT-98-33-T, par. 580.

Retrieved 04.05.2021 from https://www.icty.org/x/cases/krstic/tjug/en/krstj010802e.pdf

4. The discussion of the question of the responsibility of any contracting country referred to the Convention of genocide itself: "The Contracting Parties confirm that genocide, whether committed in time of peace or in time of war, is a crime under international law which they undertake to prevent and to punish". Cf. Convention on the Prevention and Punishment of the Crime of Genocide. Retrieved from https://www.ohchr.org/en/professionalinterest/pages/crimeofgenocide.aspx

The Draft Declaration is included as Annex I of the Report of the Working Group on Indigenous Populations on its Eleventh Session, 23 August 1993, UN Commission on Human Rights, 45th Session, Agenda Item 14. E/CN.4/Sub.2/1993/26, 8 June 199.

For the votes, see A/61/PV.107, 13 September 2007. The Russian Federation, Ukraine, Georgia, and eight developing countries abstained.

Cases with Da'esh in Iraq and Boko Haram in Nigeria, both groups were engaged in the abduction of children, targeted by religion. Cf. White House, Office of the Press Secretary, Statement by the President, August 7, 2014; and U.S. Department of State, Statement of Secretary of State John Kerry, March 17, 2016.

5. In his report of January 12, 2009, the Secretary-General indicates that "Under conventional and customary international law, States have obligations to prevent and punish genocide, war crimes and crimes against humanity. Ethnic cleansing is not a crime in its own right under international law, but acts of ethnic cleansing may constitute one of the other three crimes. The Summit's enunciation of the responsibility to protect was not intended to detract in any way from the much broader range of obligations existing under international humanitarian law, international human rights law, refugee law and international 
criminal law and implementing the responsibility to protect" (Cf. Report of the Secretary-General, 12 January 2009, A/63/677, points 2 to 3).

\section{References}

Accountability for destruction of cultural heritage: The case of Jugha. (2012). The Switzerland-Armenia Association (SAA), for consideration at the 49th session of the Committee on Economic, Social and Cultural Rights (Pre-Sessional Working Group, 21-25 May 2012), State examined: Azerbaijan. Retrieved from; http://www2.ohchr.org/english/bodies/cescr/docs/ngos/SAA_AzerbaijanWG49.pdf

Akhavan, P. (2016). Cultural genocide: legal label or mourning metaphor? McGill Law Journal, 62 (1), pp.243-270, https://doi.org/10.7202/1038713ar

Annan, K. (1998). Secretary-General says prevention of human rights violations must mark $21^{\text {st }}$ century: addressing opening of Human Rights Commission's session, stresses need to uphold Universal declaration on human rights. [ST/DPI/PRESS/]SG/SM/6487/Rev.1, [ST/DPI/PRESS/]HR/4355/Rev.1 New York: UN Department of Public Information. Retrived from https://digitallibrary.un.org/record/251755

Application of the Convention on the Prevention and Punishment of the Crime of Genocide (Bosnia and Herzegovina v. Serbia and Montenegro). (2007). ICJ reports, Judgment.

Balakian, P. (2013). Raphael Lemkin, cultural destruction, and the Armenian genocide. Holocaust and Genocide Studies, 27 (1), pp. 57-89. doi:10.1093/hgs/dct001

Bieńczyk-Missala, A. (2018). Zapobieganie masowym naruszeniom praw człowieka. Międzynarodowe instytucje i instrumenty [Preventing mass human rights violations. International institutions and instruments] Warsaw: Wydawnictwo Naukowe Scholar.

Bieńczyk-Missala, A. (2019). Kosovo: The first war for human rights. In M. Madej (ed.), Western Military Interventions After the Cold War: Evaluation of the Wars of the West, pp. 1-21, New York: Routledge.

Ben-Naftali, O. (2009). The Obligations to prevent and to punish genocide. In P. Gaeta (ed.). The UN Genocide Convention: A Commentary. (pp. 3644). Oxford University Press. 
Case concerning armed activities on the territory of the Congo (New application: 2002) (Democratic Republic of the Congo v. Rwanda). (2006). ICJ, Reports of Judgments, Advisory Opinions and Orders. 1-54.

Case of Janowiec and others v. Russia. (2013). Applications nos. 55508/07 and 29520/09. Judgment. October 21, 2013. Retrieved from https://hudoc.echr.coe.int/app/conversion/pdf/?library=ECHR\&id=00 1127684\& filename $=001-127684 . p d f$

Francioni, F. (2004). Beyond State sovereignty: the protection of cultural heritage as a shared interest of humanity. Michigan Journal of International Law, 25, 1209-1228.

Gasparyan, S., Paronyan, Sh., Chubaryan, A., \& Muradyan, G. (2016). Raphael Lemkin's draft convention on genocide and the 1948 UN Convention. A comparative discourse study. Yerevan: Yerevan State University Press.

Głogowska-Balczerzak, A. (2013). Cultural dimension of the crime of genocide. Law and Economic Studies, LXXXIX, 79-97.

Heidrich, D. (2013). Przyszłość międzynarodowych trybunałów karnych ad hoc. Strategie zakończenia oraz rozwiązania rezydualne, ze szczególnym uwzględnieniem i Międzynarodowego Trybunału Karnego dla byłej Jugosławii [The Future of International Criminal Ad Hoc Tribunals. Completion Strategies and Residual Solutions, with Special Attention to the International Criminal Tribunal for the Former Yugoslavia]. Studia Europejskie-Studies in European Affairs, 3, 159-182.

Honouring the Truth, reconciling for the future: summary of the final report. (2015). the Truth and Reconciliation Commission of Canada. Retrieved from http://www.trc.ca/websites/trcins titution/File/2015/Honouring the_Truth_Reconciling_for_the_Future_July_23_2015.pdf

Jacobs, D. (2010). The importance of being earnest: the timeliness of the challenge to admissibility in Katanga. Political Science. Leiden Journal of International Law, 153-164.

Korey, W. (2001). An epitaph for Raphael Lemkin. Pre-publication copy. New York: Jacob Blaustein Institute for the Advancement of Human Rights of the American Jewish Committee.

Kułaga, Ł. (2014). Responsibility to protect as a response of the international community to the crime of genocide. In International Humanitarian Law, V, Genocide as an International Crime. Gdynia: Naval Academy, Marine Command and Operations Department.

Lemkin, R. (1946). Genocide a new international crime punishment and 
prevention. 17 Revue Internationale de Droit Penal. Retrieved June 2, 2021, from https://undocs.org/en/A/RES/ 96(I)

Luck, E. C. (2018). Cultural genocide and the protection of cultural heritage. In J. Paul Getty Trust occasional papers in cultural heritage policy, 2, 1-38. Maghakian, S., \& Pickman, S. (2019). A regime conceals its erasure of indigenous Armenian culture. In Hyperallergic. Retrieved from https://hyperallergic.com/482353/a-regime-conceals-its-erasure-ofindigenous-armenian-culture/

Mako, Sh. (2012). Cultural genocide and key international instruments: framing the indigenous experience. International Journal on Minority and Group Rights, 19.

Morsink, J. (1999). Cultural genocide, the universal declaration, and minority rights. Human Rights Quarterly, 21(4).

Moses, A.D. (2010). Raphael Lemkin, culture, and the concept of genocide. In D. Bloxham, \& A. Dirk Moses (ds.) The Oxford Handbook of Genocide Studies, New York: Oxford University Press, pp. 19-41.

Nersessian, D. (2005). Rethinking cultural genocide under international law. Human rights dialogue: "Cultural Rights" Live Stream Newsletter, 2 (12). Carnegie Council for Ethics in International Affairs. 7-8. Retrieved September 10, 2021 from https://www.carnegie council.org/publications/archive/dialogue/2_12/index/_res/id=Attachmen ts/index $=0 /$ HRD_Cultural_Rights.pdf

Order on interim measures of protection on the application of the convention on the prevention and punishment of the crime of genocide, Bosnia and Herzegovina v Serbia and Montenegro. (1996). ICJ, Reports of Judgments, Advisory Opinions and Orders, 52.

Prevention of Armed Conflict. (2001). Report of the Secretary-General A/55/985-S/2001/574. 1 June 2001. Retrieved from https://reliefweb.int/report/world/prevention-armed-conflict-reportsecretary-general-a55985-s2001574

Raphael Lemkin Collection. Collection Identifier, Box 6, folder 2, p. 154, American Jewish Historical Society.

Raphael Lemkin Collection. Collection Identifier, Box 6, folder 5, p. 154, American Jewish Historical Society, letter of 10.10.1948.

Report of the Secretary-General. (2009). UN General Assembly. A/63/677, points 2 to 3 .

Roncalli, A. G. (2006). Journal de France, I, 1945-1948, Paris : Cerf. 
Salkiewicz-Munnerlyn, E. (2009). Interim measures of protection in the two orders of the ICJ genocide cases (Bosnia and Herzegovina v. Serbia and Montenegro. Strani Pravni Život, 1, 53-71, Retrieved from https://www.ceeol.com/search/article-detail?id=582668

Sawa, D. B. (2019). Monumental loss: Azerbaijan and the worst cultural genocide of the $21 \mathrm{st}$ century. The Guardian. Retrieved from https://www.theguardian.com/artanddesign/2019/mar/01/monumentalloss-azerbaijan-cultural-genocide-khachkars

Schabas, W. (2006). Preventing genocide and mass killing: the challenge for the United Nations. Minority Rights Group International Report. Retrieved from www.minorityrights.org/download.php?id=157

Schreiber, H. (2013). Cultural Genocide - Culturecide: an unfinished or rejected project of International Law? Culture(s) in International Relations. In Grażyna Michałowska and Hanna Schreiber (Eds.), (pp. 252-275). WUW, Warsaw, DOI: https://doi.org/10.3726/b11522 Retrieved from https://www.peterlang.com/view/ 9783631725894/chapter16.xhtml

Second Decision on the Prosecution's Application for a Warrant of Arrest, (6 May, 2019) 02/05-01/09-94. In C. Stahn (Ed.), (pp. 22-96). Retrieved from https://www.icc-cpi.int/Pages/record.aspx?docNo= ICC-02/0501/09-94

Short, D. (2010). Cultural genocide and indigenous peoples: a sociological approach. International Journal of Human Rights, 14(6), 831-46.

Szpak, A. (2012). Genocide in the jurisprudence of the Ad Hoc international criminal tribunals. Torun: Scientific Publishing House.

Study of the problem of discrimination against indigenous populations. (1982). Economic and Social Council Resolution 1982/34. Retrieved from http://ap.ohchr.org/documents/E/ECOSOC/resolutions/E-RES-198234.doc

The 2005 World Summit Outcome. (2005). UN General Assembly. par. 138140, Retrieved January 5, 2020 from www.un.org/en/prevent genocide/adviser/pdf/World\% 20Summit\%20Outcome\%20Docu ment.pdf\#page $=30$.

The responsibility to protect. (2001). Report of the International Commission on Intervention and State Sovereignty, Retrieved January 5, 2020 from http://responsibilitytoprotect.org/ ICISS\%20Report.pdf. 
The trial of Efrain Rios Montt and Mauricio Rodriguez Sanchez. (2018). In International Justice Monitor. Retrieved July 9, 2021 from http://www.riosmontt-trial.org/trial-background/ timeline-of-events/

The United Nations declaration on the rights of indigenous peoples. (2007). UN General Assembly Resolution 61/295, Annex, 13. Retrieved from https://www.un.org/development/desa/indigenouspeoples/wp-content/ uploads/sites/ 19/2018/11/UNDRIP_E_web.pdf

Wierczyńska, K. (2006-2008). The evolution of the notion of genocide in the context of the jurisdition of the national courts. XXVIII Polish Yearbook of International Law, 83-93.

Retrieved from http://www.grocjusz.edu.pl/Materials/_archiwum/archiwum 2014/js_sem_0612.pdf

Wierczyńska, K. (2015). Współczesny wymiar zbrodni ludobójstwa, Studia

Socjologiczno-Polityczne. Seria Nowa, 2(04), 31-47 Retrieved from https://www.wuw.pl/data/include/cms/Studia_Socjologiczno-Polityczne_204_2015.pdf

Wierczyńska, K., \& Jakubowski, A. (2016). Crimes against cultural heritage before the International Court of Justice: critical analysis. PAN INP Studia Prawnicze, 1 (205), 39-60.

UNCHROR, 45 ${ }^{\text {th }}$ Sess., Annex 1, Agenda Item 14, UN Doc E/CN.4/Sub.2/1993/29 (1993) [Draft Declaration].

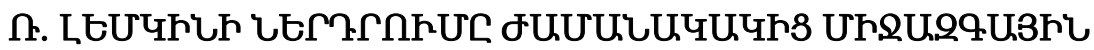

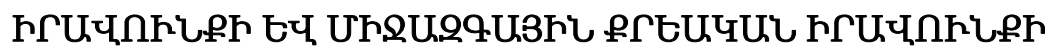 QURQUSUUU UES}

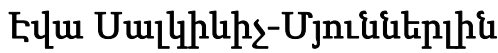

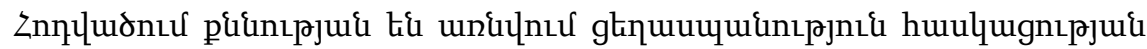

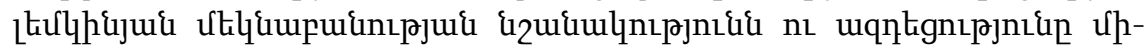

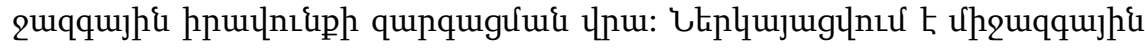

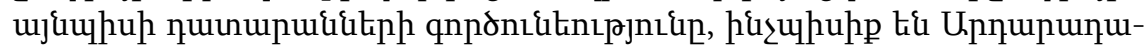

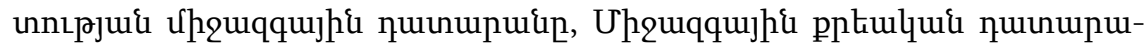

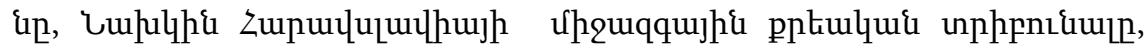

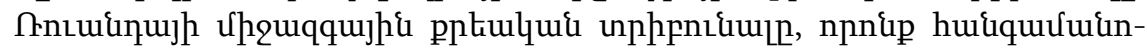

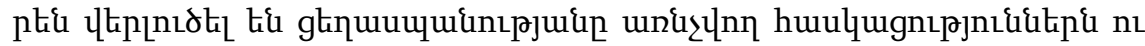

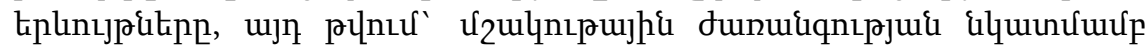

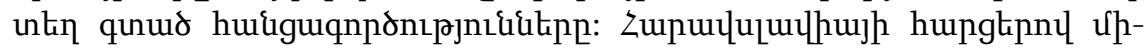

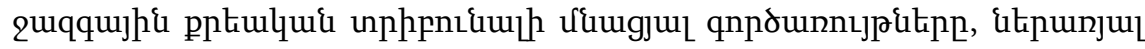

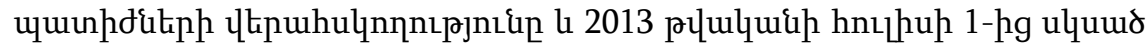




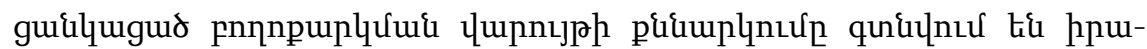

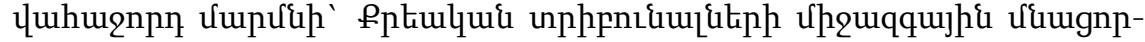

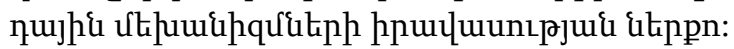

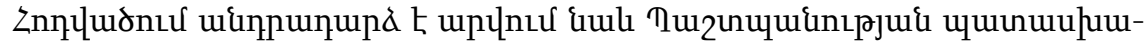

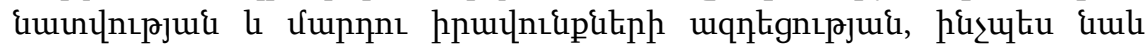

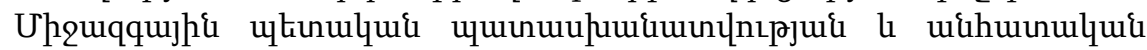

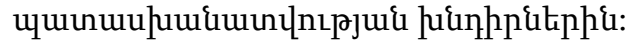

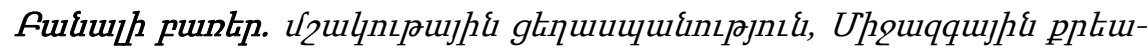

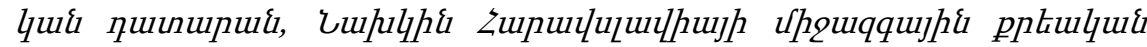

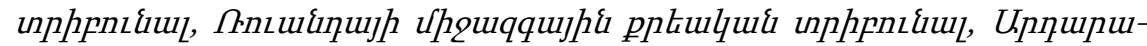

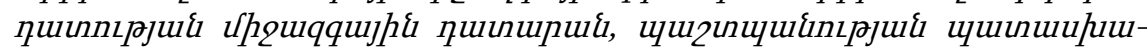

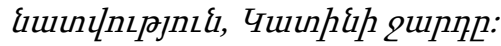

